\title{
Effect of Media Synchronization Module on Learning Achievement of the Software Engineering Students of Vocational High School
}

\author{
Muhammad Chusni Agus, Amat Mukhadis, Eddy Sutadji \\ Vocational Education, Postgraduate, State University of Malang, Indonesia \\ chusniagus@gmail.com
}

\begin{abstract}
This research aims at examining the effect of media synchronization module, mechanical aptitude, and prior knowledge on learning achievement of eleven grade students of the Software Engineering (RekayasaPerangkatLunak/RPL) Programin Vocational High School 5 at Malang, East Java, Indonesia. This quasi-experimental research used factorial design of $2 \times 2 \times 2$ pattern and applied the non-equivalent control group design. It involved 74 students who were divided into two groups; 37 students were in the experimental group and 37 students were in the control group. Tests were used to investigate the students' mechanical aptitude, prior knowledge and learning achievement. Data were analyzed by using three-way ANOVA. The results of the research showed that: 1) There was a significant difference in the learning achievement of the group taught by using media synchronization module and those who were taught by using the conventional method; 2) there was no significant difference in the learning achievement in the C++ Programming between students who had high and low mechanical aptitude; 3) there was a significant difference in the learning achievement in C++ Programming between students who had high and low prior knowledge; and 4) there was no significant interaction among media synchronization module, mechanical aptitude, and prior knowledge on the learning achievement with C++ Programming.
\end{abstract}

Keywords: Media synchronization module, mechanical aptitude, prior knowledge, learning achievement

\section{Introduction}

In Vocational High School (VHS) in Indonesia, the Computer Technology and Informatics (CTI) Program has undergone changes. More particularly, the competence development pillar changes into subject matter grouping (Permendikbud, 2013). For example, in the CTI program the Software Engineering (RekayasaPerangkatLunak/RPL) program has been established. The aim of the Software Engineering program is to provide students with knowledge, skills, and attitude so that they can be competent in software engineering. One of the expected competences in the CTI program deals with programming logic design. In general, the Software Engineering program covers skills in two compulsory subject matters: Group A and Group B subject matters. Mathematics is one of Group A subject matters which has close relation with the basic understanding of Software Engineering especially in using basic logic. According to Mulyanto (2008), "software engineering is a field of study that deals with the various aspects of production of software, starting from the first stage which is users analysis, specification of the users' needs, design, coding, testing, up to system maintenance after use." Therefore, software engineering is a form of technology to make a program by using certain codes related to logic. From the Basic Software Engineering subject matterattended by Class X students in VHS 12 at Malang, which applied analog and digital techniques, it was known that in 2009, 2010, 2011, and 2012,the students' scoreswere73.92, 72.95, 73.97, and68.08, respectively(Dinihari, 2013). The scores were used as a basis to analyze the grades in Mathematics of the students from the same school.

Mathematics is one of the Group A subject matters that have to be taught in VHS. Basic competence dealing with numbers and computation in Mathematics needs to be mastered by the students. This competence is the elaboration of competence standard developed by using operational verbs such as counting,identifying, comparing, estimating, analysis, applicating, and summarizing. Uno (2007, p.129) stated that Mathematics is a field of study that can be used as a means of communication, solution of practical problems that have logic and intuition, analysis and construction, and generalization and individualism. Winarno (2012, p.590) stated that students who are good at Mathematics answer questions correctly in a short time. The scores of Mathematics of Class X students of VHS 12 at Malang for the basic competence in solving problems related to operation of real and complex numbers such as error approximation, solution of problems related to function, linear and square equations, matrics, and multiple problems in 2009, 2010, 2011, and 2012 were 72.52, 71.36, 72.73, and 70.66, respectively (Dinihari, 2013). 
It was apparent that results of the scores of Software Engineering and Mathematics subject matters from 2009 to 2012 in VHS 12 at Malang fluctuated. It was analyzed that from the scores of the two subject matters, if the students' scores in Mathematics increased the scores of Software Engineering also increased, but if the students' scores in Mathematics decreased, the students' scores of Software Engineering also decreased. From the comparision of the scores in the two subject matters, it can be concluded that the scores of Mathematics had the same tendency as the scores of Software Engineering and therefore the two subject matters can be synchronized. To synchronize the two subject matters, a complementary activity is needed to improve the students' scores in the two subject matters. One of the ways to improve the students' scores is by applying instructional media that can cover contents relevant to the contents of Mathematics subject matter. The results of interviews conducted with Software Engineering and Mathematics teachers of VHS 5 at Malang showed that the learning achievement of VHS students were affected by a number of factors, among others: (1) student input, (2) learning method, (3) learning duration, and (4) learning media. One of the ways to improve the learning achievement of the students of VHS is developing learning materials in the various forms of media. Thus, the production of learning media entailing the learning materials are likely to improve the students' learning achievement.

It is clear then that learning media used in the class affect learning achievement. The produced learning media can be used as additional media for students' learning so that the learning process can be more effective, more interesting, and more joyful (Supiyarto \& Hartono, 2013). Ikasari and Puspitasari (2013, p.111) mentioned that teachers will be helped by the availability of learning media as students can be more active, enthusiastic, and joyful in the learning activities. The teaching media selected should be relevant with the characteristics of the subject matters because the application can attract students' attention. Consequently, teachers are required to be able to use new learning media that can be used to improve the students' learning so that it can attract the students and improve their learning achievement. Based on the condition of the learning process, it was known that students did not show their interest and enthusiasm in the learning activities. Aditionally, the instructional media used were in the form of printed modules. This condition demands the improvement in the learning media so that the use of the new media can lead to the improvement of the learning achievement. One of the learning media is encyclopedia that can be used as a reference by the teachers and the students. Encyclopedia is a universal book that has explanations on thematic entries arranged in alphabetical order(KamusBesarBahasalndonesia,2002, p.232). At the first glance, encyclopedia looks like a dictionary, but the two publications are different. The difference lies in the explanaton of the contents of the two publications. One example of encyclopedia is Encarta which was released by Microsoft, a producer of software products. However, encyclopedia discusses materials too broad, so that the materials cannot be focused on a more specified topics.

In the learning process, the Group A and Group B subject matters (which are compulsory) should allow the provision of Group C subject matters (which are elective). One way to enable the sudents to learn is to synchronize Group A and B subject maters with Group C suject matters so that the students will map their minds more easily to understand the subject matters with the help of instructional media. The effort in the synchronization should also consider the characteristics of the two subject matters. The Software Engineering subject matter can be synchronized with Mathematics subject matter because the twe two subject matters need mathematical logic. The Software Engineering is a subject matter that deals with all aspects of software production, starting from system specification to maintenance after the products are used. On the other hand, the learning of Software Engineering subject matter requires logic at the product creation stage. The Software Engineering and Mathematics subject matters are relevant because the two subject matters need computation in the process of the material completion. As a matter of fact, the Software Engineering subject matter can be synchronized with Mathematics subject matters.Synchronization at the basic competence solves the problem in using multiple control structuresin the basic programming in the Software Engineering subject matter with basic competence in prediction of arithmatic sequences and geometric configuration through observation and the reasons in Mathematic subject matter. The materials for the synchronization of Software Engineering with Mathematics subject matters are covered in the instructional media. The process in developing instructional media needs validation from experts in the materials, instructional media, and users in terms of the materials and the format of presentation. The instructional media need to be used so that the transfer of learning to the students can run welland result in better achievement. 
Apart from considering the characteristics of the instructional media and the materials, it is necessary to examine the students' mechanical aptitude. This is because logic can function as predecisors of efforts and achievement. In light of the scope of the research which is conducted in the VHS which requires students to master a particular field, it is then important to pay attention to the students' mechanical aptitude so that the effect of aptitude can be understood. Djamarah (2008, p.138) states that aptitude is potensial competence owned by individuals to attain their achivement at a particular level as indicated by the individuals' capacity. With high mechanical aptitude the process of theoretical and practical learning can be made better; In contrast, low mechanical aptitude will lead to the low achievement of theoretical and practical learning. Beside instructional media and mechanical aptitude, it is necessary to pay attention to prior knowledge. For children, prior knowledge affects the mastery of the materials taught. If students have enough prior knowledge about the materials to be taught, it will be easier for them to understand the materials taught. This is because if students' master the materials, it will be easier for them to understand the materials given in the higher level. In addition, by knowing that the students have certain prior knowledge, it will be easier for the teachers to determine the part of lesson that should be taught.

In light of the issues discussed above, this research aims at examining (1) the effect of teaching by using media synchronization module and conventional learning model completed with modules on the learning achievement of C++ Programming; (2) the effect of students with high and low mechanical aptitude on the learning achievement of $\mathrm{C}++$ Programming; (3) the effect of students with high and low prior knowledge on the learning achievement of $\mathrm{C}++$ Programming, and (4) interaction among instructional media, mechanical aptitude, and prior knowledge on learning achievement of C++ Programming of Grade XI students of the Software Engineering Program in VHS 5 at Malang.

\section{Literature Review}

In this section, the definition of keywords is presented as follows:

Synchronization is a process that sets the way a number of processes happen simultaneously to prevent some errors. According to Kamus Besar Bahasa Indonesia (Tim Redaksi, 2002), to be synchronous is to happen at the same time.

Mechanical aptitude is innate capability owned to be developed to be able to choose appropriate actions, programs or majors, to choose education, friends and so on to achieve better future. Pradana (2014, p.1) stated that mechanical aptitude is a factor that affects and ensures technical success for students.

Prior knowledge is the result of learning obtained before getting the higher level of knowledge. According to Rebber (cited in Syah, 2006, p.121), prior knowledge is a prerequisite to know any changes.

Learning achievement is the results of learning achieved by the students in the cognitive, affective and psychomotor domains obtained as a result of learning activities which are measured in a particular period. Sudjana (2010, pp.22-31) divides the results of learning into three areas: the cognitive, affective and psychomotor domains.

\section{Methodology}

This research used quasi-experimental design with factorial pattern of $2 \times 2 \times 2$, applying the non-equivalent control group design seen from the use of synchronization media module (A), mechanical aptitude (B), and prior knowledge $(\mathrm{C})$ on the students' learning achievement. 
Figure 1: The Factorial Pattern

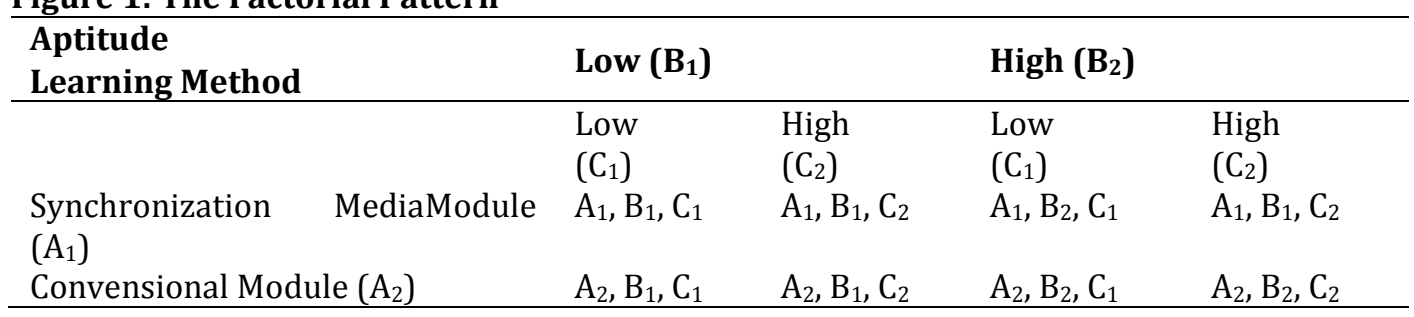

The subjects of the research were 74 Grade XI students of the Software Engeneering Program in the academic year of 2013/2014. The students were divided into two groups: 37 students in the experimental group and 37 students in the control group.

The measurement of mechanical apitude was conducted by a team of lecturers from State University of Malang, one of the leading universities in Indonesia.Data on the students' prior knowledge were gathered from the classroom teacher and the learning achievement data were gained from a test which had been validated by material and media experts who were also lecturers of the university. The datawere analyzedby using three-way ANOVA to know the contribution among A, B, and C variables.

\section{Results and Discussion}

The results of the research analyzed by using SPSS 18 program showed the following:

a) $\mathrm{Ho}$ is accepted if the level of confidence is more than 0.05 .

b) Hois rejected if the level of confidence is less than 0.05 .

IfHois accepted, it means that there is no effect or no interaction, while ifHois rejected itmeans that there is effect or interaction. The summary of the ANOVA tests is shown in Table 1.

Table 1: Summary of the Results of Analysis of Variants (Source: Treatment, Mechanical Aptitude, and Prior Knowledge))

\begin{tabular}{lllll}
\hline NO & Source & Df & F & Sig. \\
\hline & Group & 1 & 19.518 & .000 \\
& Mechanical_apt & 1 & .887 & .351 \\
& Prior_knowl & 1 & 77.899 & .000 \\
& Group * Mechanical_apt & 1 & 2.118 & .152 \\
& Group * Prior_knowl & 1 & .067 & .797 \\
& Mechanical_apt * prior_knowl & 1 & .134 & .716 \\
& Group * mechanical_apt * prior_knowl & 1 & .420 & .520 \\
\hline
\end{tabular}

\section{Effect of Media Synchronization Module on Learning Achievement of C++ Programming}

The results of the research showed that: First, there is a significant diffence between the learning achievement of the students taught by using module synchronization media (70.63) and those taught by using conventional learning model (60.39) completed with modules on the learning achievement of $\mathrm{C}++$ Programming in VHS 5 at Malang. The result of the study supports the finding of previous research. For example, Nugrahini (2012, p.201) reported that the application of instructional media in the form of moduleentitled "Application of Basic Data for Grade X of Software Engineering Program in VHS" improved the students' understanding of theories and practices in applying data and optimize their learning achievement. This research is confirming the results of the research conducted by Kusmiyati (2014), Primavera andSuwarna (2014), andSupiyartoand Hartono (2013) who have reported that there is significant and positive correlation between the use of instructional media and learning achievement. 


\section{Effect of Mechanical Aptitude on Learning Achievement of C++ Programming}

The result of the analysis showed that there is no significant difference in the students' learning achievement between those who had high $(71.21$ by using media synchronization module and 57.62 by using conventional learning model) and low (70.18 by using media synchronization module and 63.17by using conventional learning model) mechanical aptitude on the learning achievement of C++ Programming in VHS 5 at Malang. This was in line with the research of Maryani (2012, p.174) which explained that mechanical aptitude manifests in the characteristics of people who have the ability to develop their knowledge and skills which can be improved through practices. Aptitude contains inherited ability which needs to be developed and trained. The result of this study was supported by earlier research results which were reported byHaryati et al. (2013) andMaryani (2012) which showed that there were no significant relations between mechanical aptitude and learning achievement.

\section{Effect of Prior Knowledge on Learning Achievement of C++ Programming}

There is a significant difference between the students with high prior knowledge (80.52 by using media synchronization module and 70.90 by using conventional learning model) and those with low prior knowledge ( 60.71 by using media synchronization module and 49.89 by using conventional learning model)on the learning achievement of C++ Programming in VHS 5 at Malang. This is relevant to what is stated by Nendi et al. $(2013$, p.11) that prior knowledge contributes positively to the high or low learning achievement. The result of this research is supported by research studies conducted by Praptiwi and Handika (2012)as well as Dinihari (2013) which showed that there is a significant and positive relation betwen prior knowledge and learning achievement.

Interaction among Media Synchronization Module, Mechanical Aptitude, and Prior Knowledge and Learning Achievement of C++ Programming

From the result of testing the fourth hypothesis it was known that there was no significant interaction between the treatment, mechanical aptitude, prior knowledge, on the learning achievement of $\mathrm{C}++_{+}$ Programmingat 0.520 significance level in VHS 5 at Malang. The effect of the independent variables on the learning achievement can be known through the variants by interpreting the results of the computation by using ANOVA. The variant of learning achievement resulted from the effect of media sychronization module was 0.000 showing that there was a significant effect. This finding conforms to Fatah $(2005$, p.123) who stated that teaching and learning process will be effective if professional tachers are able to synchronize instructional media and teaching methods. This also conforms to research conducted by Anggraini (2013) which found that there is a positive and significant relation between learning achievement and prior knowledge.

\section{Conclusion and Recommendations}

Basedon the results of research and discussion, it can be concluded as follows: First, there is a significant difference between the learning achievement of the students taught by using mediasynchronization module (70.63) and those taught by using conventional learning model completed with modules (60.39). Second, there is no significant difference between students who had high(71.21 by using mediasynchronization module and 57,62 by using conventional learning model) and low(70.18 by using mediasynchronization module and 63.17 by using conventional learning model) mechanical aptitude on the learning achievement of $\mathrm{C}++$ Programming. Third, there is a significant difference between the students with high prior knowledge ( 80.52 by using mediasynchronization module and 70.90 by using conventional learning model) and those with low prior knowledge ( 60.71 by using mediasynchronization module and 49,89 by using conventional learning model)on the learning achievement of $\mathrm{C}++$ Programming. Fourth, there is no significant interaction among instructional media, mechanical aptitude, and prior knowledge on learning achievement of $\mathrm{C}_{++}$ Programming. Thus, the group which improved the learning achievement optimally was the one which used media synchronization module with high mechanical aptitude and high prior knowledge with the mean 80.79. 
In light of the results of research and discussion, some recommendation for State VHS 5 at Malang are put forward as follows. The VHS needs development of media synchronization module in another basic competence of $\mathrm{C}++$ Programming and guidance for students who have difficulty in learning.

\section{References}

Anggraini, V. D. (2013). Effect of problem-based learning model completed with module, learning motivation, and prior knowledge on learning achievement of C++ programming students of VHS. Unpublished Masters Tesis. Malang: Graduate School, State University of Malang, Indonesia.

Dinihari, P. (2013). The improvement of the quality of chemical association learning process and achievement of grade X students of the software engineering program of VHS 12 at Malang through teams games tournament cooperative learning and students' modality. JurnalInspirasiPendidikan, 3(1), 185-195.

Djamarah, B.S. (2008). The psychology of learning. Jakarta: PT RinekaCipta.

Fatah, S. (2005). Educational technology. Semarang: RASAIL.

Haryati, P. S., Yudana, M.,\&Candiasa, I. M. (2013). The effect of the application of STAD cooperative learning on the learning of Mathematics of Grade X students of state VHS 3 at Singaraja viewed from Numerical aptitude. School of Graduate Studies,UniversitasPendidikanGanesha, Singaraja. Retrieved April 23, 2015, from http://pasca.undiksha.ac.id/e-journal/index.php/ jurnal_ep/article/view/733/519

Ikasari, I.,\&Puspitasari, T. (2013). Interactive learning media for basic operation of computer in VHS 1 at Boyolali.Seminar RisetUnggulanNasionalInformatikadanKomputer,2(1), 108-113.

Kusmiyati, A. (2014). The development of basic structure of algorythm module on MAPTD subject matter for students of software engineering at the first semester of grade X in VHS at Krian. JurnalMahasiswa Teknologi Pendidikan, 2(2). Retrieved April 10, 2015, from http://ejournal.unesa.ac.id

Maryani, P. (2012). The contribution of mechanical aptitude and learning process on productive subject matters towards competence and readiness to work in industrial field. Unpublished Masters Thesis. Bandung: Universitas Pendidikan Indonesia.

Mulyanto, A. R. (2008). Software engineering for vocational high school. Jakarta: Depdiknas.

Nendi, F., Dantes, N., \& Suarni, N. K. (2012).Effect of contextual teaching and learning with performance assessment on the learning of the basic concept of mathematics involving numerical competence and learning motivation as covariates. Program Pascasarjana Universitas Pendidikan Ganesha, 3, 1-12.

Nugrahini, N. P. P. (2012). The development of learning module for application of basic data by using SQ3R for students of software engineering in VHS 1 at Negara. Jurnal Nasional Pendidikan Teknik Informatika, 1(3), 191-202.

Permendikbud (2013). Appendix of the regulation of the ministry of education and culture no 70/2013 on the basic framework and structure of the vocational high school or Islamic vocational high school. Jakarta: Permendikbud.

Pradana, A. W. (2014). The work readiness of the students of engineering technique viewed from mechanical aptitude and learning achievement. E-JurnalPendidikan Teknik Mesin, 2(3). 1-8.

Praptiwi\&Handika, J. (2012). The effectivene of GI and STAD cooperative learning viewed from prior knowledge. JurnalPenelitianPembelajaranFisika, 3(1), 41-50.

Primavera, I. R. C., \&Suwarna, I. P. (2014). Effect of audio visual media on the learning achievement of grade XI students on the concept of elasticity. ProsidingSeminarnasionalPendidikan IPA FITK UIN SyarifHidayatullah Jakarta, 122-129.

Sudjana, N. (2010).Assessment of the result of the learning concept. Bandung: PT. Remaja Rosdikarya.

Supiyarto, B., \& Hartono (2013). The creation of instructional media for KKPI in Muhammadiyah VHS 1 at Boyolali. Seminar RisetUnggulanNasionalInformatikadanKomputer, 2(1), 28-36.

Syah, M. (2006). The psychology of learning. Jakarta: PT. Raja GrapindoPersada.

Tim Redaksi. (2002). Big dictionary of Indonesian language. Jakarta: Balai Pustaka.

Uno, H. B. (2007). The instructional model for creative and effective teaching and learning. Jakarta: BumiAksara.

Winarno (2012). The development of computerized adaptive testing by using the triangle-tree decision. PenelitiandanEvaluasiPendidikan, 16(2), 574-592. 